\title{
ВЗАЕМОЗВ'ЯЗОК ДЕСТРУКТИВНИХ ПСИХІЧНИХ СТАНІВ ПРАЦІВНИКІВ УСТАНОВ ВИКОНАННЯ ПОКАРАНЬ 3 ПРОФЕСІЙНИМ ВИГОРАННЯМ ТА ПРОФЕСІЙНОЮ ДЕФОРМАЦІЄЮ
}

УДК: 159.9.07:355.12(045)

\section{Чичуга Марина Михайлівна}

Кандидат психологічних наук, старший викладач кафедри практичної психології Інституту кримінально-виконавчої служби, м. Київ (Україна)

\begin{abstract}
Анотація. У статті проаналізовано взаємозв'язки деструктивних психічних станів працівників соціально-психологічної служби установ виконання покарань з компонентами професійного вигорання та професійною деформацією.

Зазначено, щзо за результатами емпіричного дослідження у працівників СПС УВП виявлено ситуативну та особистісну тривожність, напругу, страх, середній рівень професійного вигорання. Досліджено початковий рівень професійної деформачії в осіб, які працюють в УВП менше 5 років та середній ступінь в працівників зі стажем служби в УВП більше 5 років.

Виявлено кореляційні зв'язки ситуативної та особистісної тривожності, а також напруги з професійним вигоранням працівників сочіально-психологічної служби установ виконання покарань, які свідчать, щ⿻о при підвищенні тривожності та напруги підвищується рівень професійного вигорання. Встановлено прямі корелячійні зв'язки між ситуативною тривожністю та професійною деформацією у респондентів, які працюють в УВП більше 3 років. Зазначено, щчо при підвищенні стану тривоги в респондентів підвищується рівень професійної деформації.
\end{abstract}

Ключові слова: деструктивні психічні стани, професійне вигорання, емоційне виснаження, деперсоналізація, редукиія особистих досягнень, професійна деформація, працівники установ виконання покарань.

\section{Постановка проблеми. Професійне} вигорання та професійна деформація є досить актуальною проблемою для персоналу установ виконання покарань (далі - УВП). Це зумовлено, в першу чергу, економічною кризою в державі, недоліками в кадровій та організаційній сфері Державної кримінально- виконавчої служби України та, безпосередньо, негативними психічними станами працівників УВП, якостями особистості, відношенням до служби, вмінням вирішувати складні завдання та конфліктні ситуації.

Явища професійного вигорання та професійної деформації є дотичними до теми де- 
структивних психічних станів персоналу УВП. Ці стани можуть проявлятися внаслідок наявних в працівників установ виконання покарань тих чи інших видів професійних деструкцій, або призводити до їхньої появи.

Зазначимо, що деструктивні психічні стани працівників установ виконання покарань - це негативні психічні стани, які на різних етапах проходження служби мають свою специфіку та здійснюють значний вплив на ефективність та результати професійної діяльності і зумовлюють негативні зміни в структуpi особистості працівників [4]. Такими станами можуть бути: тривога, напруга, страх, депресія, агресія, фрустрація, апатія тощо.

Аналіз останніх джерел і публікацій. Вивченню ролі негативних психічних станів в контексті особливостей професійної діяльності працівників Державної кримінальновиконавчої служби присвячені роботи українських науковців та дослідників. Так, особливості прояву окремих психічних станів працівників ДКВС у професійній діяльності досліджувала М. Ятчук. Оцінкою та психокорекцією психічних станів працівників органів та установ виконання покарань займалися Н. Гук, В. Медвєдєв, Т. Якимчук. Питання профілактики та нейтралізації негативних психічних станів працівників Державної кримінально-виконавчої служби розробляла Т. Кушнірова.

Проблему професійного вигорання працівників, які відносяться до професій типу «людина-людина» досліджували, як зарубіжні вчені (К. Боффі, Р. Б’янкі, С. Джексон, М. Лейтер, І. Лоран, І. Лоурент, К. Маслач, Г. Норс, Д. Тручот, Г. Фрейденбергер, К. Хайнгрей, А. Шонфельд), так і українські (Н. Булатевич, Н. Водоп'янова, Л. Юр'єва та інші). Дослідники зауважували, що професійне вигорання може супроводжуватися негативними психічними станами, зокрема, напругою, депресією тощо.

Профілактикою та корекцією професійної деформації працівників УВП займалися Н. Максимова, В. Медвєдєв, О. Сахнік, В. Синьов та інші. Вчені зазначали, що в процесі розвитку професійної деформації в працівників можуть виникати страх, тривога тощо.

Незважаючи на значні наукові розробки, проблема взаємозв'язку професійного вигорання 3 деструктивними психічними станами працівників установ виконання покарань, потребує більш поглибленого вивчення, що і зумовило вибір теми нашого дослідження.

Мета статті полягає в аналізі взаємозв'язків деструктивних психічних станів працівників установ виконання покарань 3 компонентами професійного вигорання та професійною деформацією.

\section{Завдання:}

здійснити науково-теоретичний аналіз зв'язку деструктивних психічних станів працівників установ виконання покарань 3 професійним вигоранням та професійною деформацією; 
- проаналізувати особливості деструктивних психічних станів, професійного вигорання та професійної деформації працівників соціально-психологічної служби установ виконання покарань;

- $\quad$ встановити взаємозв'язки деструктивних психічних станів працівників соціальнопсихологічної служби установ виконання покарань 3 компонентами професійного вигорання;

- встановити взаємозв'язки деструктивних психічних станів працівників соціальнопсихологічної служби установ виконання покарань 3 професійною деформаці$€ ю$.

Виклад основного матеріалу. В службовій діяльності працівників установ виконання покарань поява деструктивних психічних станів пов'язана зі специфічними умовами праці, ризиком, постійним спілкуванням з засудженими тощо.

Деструктивні психічні стани можуть змінюватися, проте, вони мають тенденцію до постійності, що проявляється в таких індивідуальних характеристиках, як професійне вигорання та професійна деформація.

Значний вклад у дослідження професійного вигорання зробили такі зарубіжні вчені: С. Джесон, М. Лейтер, К. Маслач [10]. Дослідники зауважували, що вигорання - це синдром емоційного виснаження, деперсоналізації та редукції особистих досягнень, він може виникати у тих осіб, які працюють 3 людьми.
Вигорання, як стверджують науковці, - це «відповідь на хронічне емоційне напруження в інтенсивній справі з іншими людьми, особливо, якщо в них $є$ проблеми або вони дуже стурбовані». Тому, дослідники зазначали, що вигорання можна вважати одним із типів професійного стресу. Проте, вони також звертали увагу, що цей тип стресу має такі ж згубні наслідки, як й інші реакції на стрес. Разом з тим, унікальним для вигорання, як писали науковці, є те, що «стрес виникає через соціальну взаємодію між тим, хто надає допомогу і тим, хто їі отримує» $[9$, с. 2].

Відповідно до моделі соціальних психологів К. Маслач та С. Джексон синдром професійного вигорання складається 3 таких компонентів: емоційної виснаженості, деперсоналізації (цинізму) та редукції особистих досягнень [10;11].

Українська дослідниця Н. Водоп'янова стверджувала, що емоційне виснаження відчуття спустошеності і втоми, що виникає власне через роботу. Деперсоналізація передбачає байдуже, негуманне та цинічне ставлення до роботи та до її об'єктів. Третій компонент - редукція особистих досягнень - виникнення у працівників почуття некомпетентності в своїй професійній сфері, усвідомлення неуспішності в ній [3, с. 6]. Також редукція особистих досягнень полягає в негативній оцінці власних професійних досягнень та самого себе, спрощенні та обмеженні професійних обов'язків [1, с. 68]. 
Психологи Г. Фрейденбергер і Г. Норс в своїх дослідженнях стверджували, що процес вигорання можна поділити на 12 етапів, які не обов'язково відбуваються послідовно [8]. Аналізуючи ці етапи, ми помітили, що вони супроводжуються деструктивними психічними станами та характеристиками особистості, які впливають на рівень професійного вигорання.

До етапів професійного вигорання за Г. Фрейденбергером і Г. Норсом відносяться:

1) примус у самоствердженні, який зустрічається на початку професійної діяльності. Це надмірне честолюбство, бажання працівників проявити себе на роботі, що перетворюється на примус;

2) надмірна, старанна праця. Для того, щоб виправдати очікування керівництва, працівники зосереджуються виключно на роботі, а щоб показати, що вони $є$ цінними та незамінними - виконують обов'язки тільки самостійно, що може виснажувати та втомлювати;

3) нехтування своїми потребами. На цьому етапі люди весь свій час присвячують роботі, а друзі, сім'я, їжа та сон стають непотрібними або неважливими, тому, що забирають час та енергію, яку можна витратити на роботу;

4) витіснення конфліктів. Працівники починають усвідомлювати свої неправильні дії та вчинки, але виявити джерело проблеми вони не можуть;

5) перегляд цінностей. При цьому відбувається заперечення основних фізичних по- треб, змінюється система цінностей. Робота забирає всю енергію, не залишаючи нічого для відпочинку, друзів та захоплень і стає новою системою цінностей;

6) заперечення проблем, які виникають. На даному етапі люди можуть стати нестерпними і відчуженими від соціуму, агресивними, тривожними, проявляти сарказм;

7) абстрагування (вилучення, усунення). Мінімальний соціальний контакт перетворюється на ізоляцію. Алкоголь або наркотики використовуються в якості звільнення від нав'язливих ідей виконувати обов'язки відповідно до вказівок, які прописані в наказах, постановах, розпорядженнях, підручниках. Такі особи часто втрачають надію на краще;

8) очевидні зміни в поведінці, які не можуть не помічати колеги, сім'я, друзі;

9) деперсоналізація. 3'являється цинічне і негативне ставлення до роботи та іiі до об'єктів;

10) спустошеність. Працівники відчувають порожнечу в душі і можуть перебільшувати $з$ переїданням або сексуальними потребами для того, щоб подолати відчуття спустошеності;

11) депресія. Людина змучена, відчуває безнадію, байдужість і вірить, що життя не має сенсу;

12) синдром вигорання. Особистість руйнується фізично і емоційно, при цьому необхідною є допомога медиків. В особливих випадках можуть виникати суїцидальні думки $[8]$. 
Таким чином, аналізуючи 12 етапів професійного вигорання, які розробили Г. Фрейденбергер і Г. Норс варто сказати, що цей синдром супроводжується деструктивними психічними станами та характеристиками особистості такими як: агресія, байдужість, депресія, тривожність, цинізм, спустошеність, безнадія.

Також відповідно до аналізу етапів професійного вигорання можемо припустити, що в працівників УВП в процесі професійного вигорання відбувається зміна цінностей, вони можуть нехтувати своїми потребами, друзями, близькими та відпочинком, закриватися від оточуючих. Змінюється їхня поведінка, психічні стани та якості, працівники стають агресивними, нестерпними, можуть проявляти сарказм та цинізм по відношенню до засуджених. Характерними для персоналу УВП з синдром професійного вигорання будуть такі стани як спустошеність, апатія та депресія.

Той факт, що професійне вигорання супроводжується деструктивними психічними станами підтверджується дослідженнями зарубіжних вчених Р. Б'янкі, А. Шонфельда, I. Лорана. Науковці доводять, що близько 90\% працівників з синдромом професійного вигорання відповідали діагностичним критеріям депресії. При цьому дослідники припускали, що вигорання може бути депресивним синдромом, а не окремим явищем [6]. Також ідея про те, що вигорання є формою депресії була підтверджена дослідженнями таких зарубіж- них вчених: К. Боффі, Р. Б’янкі, І. Лоурента, Д. Тручота, К. Хайнгрея [7].

Український вчений В. Медвєдєв звертав увагу на дослідження зарубіжних (Дж. Гейнса, Р. Бурка, Г. Деща) та вітчизняних науковців (Н. Булатевич) серед поліцейських і працівників служби охорони, які засвідчують, що професійне вигорання супроводжується підвищеною тривожністю, емоційною нестійкістю, схильністю до ситуативних дій, підозрілістю, недисциплінованістю і напруженістю [1, с. 68]. Тому можна припустити, що ці стани та якості негативно впливають на професійне вигорання працівників УВП, можуть прискорити його процес та спричинити деструктивний вплив на здоров'я персоналу.

Зазначимо, що деструктивні психічні стани здійснюють вплив також на і професійну деформацію працівників УВП. При цьому, варто враховувати той факт, що професійне вигорання і професійна деформація тісно пов'язані між собою. В. Медвєдєв наголошував, що особливо високий рівень деперсоналізації, може свідчити про наявність професійної деформації, а емоційне виснаження працівника слід розглядати, як сприятливу умову (стан) для виникнення чи розвитку професійної деформації [1, с. 71].

Професійна деформація дещо відрізняється від професійного вигорання. В. Медвєдєв писав, що професійна деформація пенітенціарного співробітника - це комплекс специфічних, взаємопов'язаних змін особистості, 
що виникають в результаті виконання протягом певного часу правозастосувальної діяльності як основної професії [2, с. 12].

В. Медвєдєв зауважував, що ці зміни в особистості працівника установ виконання покарань виявляються у:

1. «гіпертрофії професійно важливих рис, подальшій їх трансформації в свою протилежність» [2, с. 12];

2. «актуалізації і розвитку соціальнонегативних рис, а саме, жорстокості, мстивості, брутальності, вседозволеності» [2, с. 13];

3. «пригніченні та подальшій атрофії окремих рис, які починають оцінюватись співробітником як другорядні, а то й зайві» $[2, \mathrm{c}$. 12-13];

4. «неузгодженому, дисгармонійному співвідношенні окремих рис та їх груп» [2, c.13].

Тому, можемо сказати, що професійна деформація працівників УВП супроводжується такими деструктивними психічними станами, як: розчарування, сум, емоційне збіднення; та рисами: підозрілістю, самовпевненістю, цинізмом, байдужістю, жорстокістю. Ці стани та риси особистості впливають на розвиток професійної деформації і можуть виникнути на будь-якому рівні професійної деформації.

В. Медвєдєв визначав три рівні професійної деформації працівників установ виконання покарань: початковий, середній та глибинний. Вчений зауважував, що при відсутності заходів з профілактики та корекції профе-

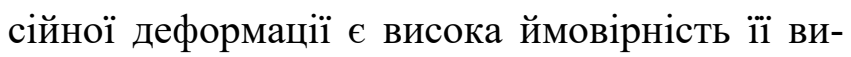
никнення в осіб, які працюють в УВП більше 15 років [1, с. 26].

Проте, В. Медвєдєв підкреслював, що деформованість працівників пенітенціарних установ залежить не тільки від стажу служби в установі, а й від сили деформуючого впливу, що об’єктивно залежить від конкретної службової діяльності та інших факторів.

Отже, аналіз наукової літератури показав, що деструктивні психічні стани та особистісні якості впливають на появу професійного вигорання та професійної деформації працівників УВП, збільшують їх рівень та негативний вплив на особистість. Зокрема, агресія, цинізм, апатія, депресія, спустошеність, безнадія, які виникають на етапах розвитку професійного вигорання можуть призвести до негативних особистісних змін. Також відповідно до досліджень вчених, ми вияснили, що професійне вигорання може супроводжуватися підвищеною тривожністю, емоційною нестійкістю, схильністю до ситуативних дій, підозрілістю, напруженістю.

В процесі професійної деформації, як свідчать численні дослідження науковців, виникають такі деструктивні психічні стани та характеристики особистості як: тривога, страх, напруга, підозрілість, самовпевненість, прискіпливість, жорстокість, агресивність, розчарування, сум, імпульсивність тощо. Вони можуть призводити до розвитку глибинного рівня професійної деформації та негативно 
впливати на здоров'я працівників УВП.

Мета нашого дослідження полягала у виявленні взаємозв'язків деструктивних психічних станів працівників УВП з компонентами професійного вигорання та професійною деформацією.

У емпіричному дослідженні застосовувався комплекс психодіагностичних методик: проводилася серед працівників соціальнопсихологічної служби установ виконання покарань України. У емпіричному дослідженні взяли участь 180 осіб чоловічої статті, віком від 23 до 40 років, які мають вищу юридичну освіту та працюють на посадах начальників відділень соціально-психологічної служби (далі - СПС) установ виконання покарань.

Таблиця 1

\section{Розподіл респондентів залежно від стажу службової діяльності в УВП}

\begin{tabular}{|l|l|l|}
\hline Назва групи & Кількість років служби в УВП & Кількість осіб \\
\hline I & До 1 року & 44 \\
\hline II & $1-3$ роки & 72 \\
\hline III & $3-5$ років & 26 \\
\hline IV & $5-10$ років & 20 \\
\hline V & $10-15$ років & 18 \\
\hline
\end{tabular}

«Шкала оцінювання ситуативної та особистісної тривожності Ч. Спілберга - Ю. Ханіна», методика виявлення нервово-психічної стійкості В. Рибнікова «Прогноз 2», опитувальник для визначення рівня професійної деформації «ОПД» В. Медвєдєва, опитувальник на визначення рівня професійного вигорання «MBI», розроблений К. Маслач, С. Джексон та адаптований В. Медвєдєвим, «16-ти факторний особистісний опитувальник Р. Кеттелла (16PF105 - C)». Для встановлення взаємозв'язків деструктивних психічних станів з професійним вигоранням та професійною деформацією використовувалася лінійна кореляція Пірсона, з використанням програми IBM SPSS Statistics 21.0.

Дослідно-експериментальна робота
Залежно від стажу службової діяльності в установах виконання покарань досліджувані були розділені на групи (Таблиця 1). Респонденти цих груп, методом випадкової вибірки, в кількості 26 осіб з кожної групи, стали основою для подальшої частини дослідження. IV-a та V-а групи були об'єднані в одну, тому, що статистично значимих відмінностей між ними не виявлено.

Результати емпіричного дослідження свідчать про наявність таких деструктивних психічних станів у працівників СПС УВП як: тривожність, напруга, страх, емоційне виснаження, деперсоналізація.

Для початку зосередимо увагу на показниках тривожності. Відповідно до отриманих даних за методикою «Шкала оцінки рівня си- 
туативної та особистісної тривожності Ч. Спілберга, Ю. Ханіна», у всіх досліджуваних групах виявлено низький рівень ситуативної тривожності (у I-й 25,06 балів; у II-й - 23,47; у IIIй - 27,18; у IV-й - 28,80; у V-й - 29,33), що свідчить про спокій респондентів, а також може говорити про те, що досліджувані приховують високу тривогу.

Рівень особистісної тривожності в І-й групі складав 42,55 балів; у II-й - 38,47 балів; III-й - 39,82 бали; IV-й - 39,55 балів; V-й 40,00 балів, тобто підвищеним він $є$ лише в I-й групі і характеризує респондентів як неспокійних, чутливих до емоційного стресу, таких, що мають проблеми з саморегуляцією. В інших групах виявлений середній рівень особистісної тривожності, який свідчить про те, що в напружених ситуаціях в працівників СПС буде адекватна реакція і вони зможуть контролювати свої емоції.

Варто зауважити, що результати проведеного М. Ятчук дослідження окремих психічних станів працівників ДКВС свідчать, що низький рівень ситуативної тривожності та середній рівень особистісної тривожності спостерігається також у працівників інших структурних підрозділів органів та установ виконання покарань, зокрема, відділу нагляду та безпеки, відділу по роботі з особовим складом тощо [5].

За допомогою 16-ти факторного особистісного опитувальника Р. Кеттелла (16PF105 - C) у респондентів всіх досліджува- них груп виявлено середній рівень напруги, що свідчить про тенденцію до фрустрації, тривоги. При цьому досліджено, що з роками служби рівень напруги у працівників збільшується. Також нами виявлено низький рівень сміливості у молодих начальників відділень СПС (до 3 років служби в УВП), який вказує на страх (боязкість) (у I-й групі - 5,00 балів, II-й $5,37)$. Встановлено, що в респондентів, які працюють в УВП більше 3 років рівень страху нижчий, ніж у тих осіб, які працюють менше 3 років.

Результати статистичної обробки даних свідчать про виявлений початковий рівень професійної деформації у начальників відділень СПС, які працюють в УВП менше 5 років та середній в тих осіб, які служать в установах більше 5 років.

Зауважимо, що початковий рівень професійної деформації характеризується тим, що він не спричиняє сильний негативний вплив на результативність професійної діяльності. На даній стадії професійна деформація ще виконує свого роду функцію психологічного захисту від негативних факторів службової діяльності, тобто працівники можуть переключатися 3 стресових професійних дій на відпочинок, прослуховування музики, обід, прогулянки. Може бути також і навпаки, якщо особа обтяжена особистісними, сімейними проблемами, вона завантажує себе роботою.

Працівникам з наявною першою стадією професійної деформації важко подолати 
тиск керівництва, колег, а також засуджених. Найбільше це стосується молодих працівників, особливо в перші місяці служби в установах виконання покарань. Крім того, ці особи можуть легко піддаватися на шантаж та маніпуляції засуджених.

Середній рівень професійної деформації характеризуються стійкими проявами упередженого відношення до засуджених та порушенням нормативно-правової регламентації службової діяльності. В. Медвєдєв стверджував, що в таких працівників УВП підвищується самооцінка, в розмові вони починають вживати жаргонні слова та вирази, загострюється ставлення до критики. Під час виконання службових завдань в цих осіб можливе виникнення окремих зривів, які вони самі пояснюють випадковими, такими, що виникають через зовнішні обставини, які від них не залежать, наприклад, політику, погану погоду тощо [2].

Також нами виявлено середній рівень професійного вигорання, майже, у всіх досліджуваних групах респондентів, зокрема, у II-й $(21,47)$, III-й - $(21,00)$, IV-й $(19,70)$ та V-й $(23,00)$ групах. У I-й групі досліджено підвищений рівень емоційного виснаження $(25,48)$. Такі показники свідчать про втому працівників СПС УПВ від роботи та емоційну перенасиченість.

Високий рівень деперсоналізації виявлено у I-й $(16,25)$, II-й $(14,72)$ та V-й $(15,67)$ групах, який полягає в цинізмі і негативному ставленні працівників до роботи та її об’єктів.
У III-й $(12,27)$ та IV-й $(11,45)$ групах встановлено середній рівень деперсоналізації.

Низький рівень редукції особистих досягнень виявлений у I-й $(29,16)$ та II-й $(31,61)$ групах. Це свідчить про те, що працівники можуть гідно оцінити свої досягнення, але іноді в них може виникати негативна оцінка власних професійних досягнень, тому, що рівень їхної редукції досягнень наближений до середнього. У III-й $(32,36)$, IV-й $(32,30)$ та V-й $(33,33)$ групах встановлено середній рівень редукції досягнень, який свідчить, що в працівників може виникати почуття некомпетентності в своїй професійній сфері.

3 метою виявлення взаємозв'язків деструктивних психічних станів 3 компонентами професійного вигорання ми провели кореляційний аналіз між рівнем тривожності («Шкала оцінки рівня ситуативної та особистісної тривожності Ч. Спілберга, Ю. Ханіна») та рівнем професійного вигорання (опитувальник «MBI» К. Маслач - С. Джексон) за допомогою лінійної кореляції Пірсона.

В I-й групі виявлений кореляційний зв'язок між особистісною тривожністю і таким компонентом професійного вигорання, як деперсоналізація, де $\mathrm{r}=-523$ при $\mathrm{p} \leq 0,013$. Кореляційний зв'язок зворотний, тобто в даному випадку при підвищенні особистісної тривожності в молодих начальників відділень СПС зменшується негативне та цинічне ставлення до роботи та засуджених, і навпаки, чим більше працівники будуть негативно та циніч- 
но відноситися до своєї роботи та її об'єктів, тим нижчий буде рівень особистісної тривожності. Така кореляція може означати байдужість працівників до своєї роботи та ії результату.

B IV-й групі (5 - 15 років служби) також існує кореляція між особистісною тривожністю та деперсоналізацією, де $\mathrm{r}=0,494$ при $\mathrm{p} \leq 0,002$, але зв'язок $є$ прямо пропорційним. Відповідно можемо говорити, що при підвищенні особистісної тривожності в начальників відділень СПС, які працюють в УВП більше 5 років підвищується рівень деперсоналізації, тобто цинізму в роботі з засудженими та негативного ставлення до своєї роботи.

Така різниця, на нашу думку, пов'язана зі стажем служби працівників в УВП. Молоді фахівців, які працюють менше року в установах, більше хвилюються за результат виконання службових завдань та за свій професійний розвиток і кар'єру. В перший рік служби в них відбувається адаптація до умов та специфіки професійної діяльності, тому рівень тривожності проявляється більше, але враховуючи невеликий досвід роботи та переживання за кар'єру, негативне відношення до об'єктів своєї роботи буде менше. Проте, при підвищенні рівня деперсоналізації, тобто при збільшенні проявів цинізму в роботі з засудженими тривожність зменшуватиметься. Така тенденція свідчить про можливу зміну якостей та рис начальників відділень СПС, які працюють в УВП до 1 року в негативну сторону.
Після 5 років (IV-a група) служби в установах якості особистості деформуються, відповідно змінюється ставлення начальників відділень СПС до засуджених, підвищуються тривожність, підозрілість, цинізм тощо. Досить часто працівники можуть не помічати у себе ці зміни, а негативізм в роботі з засудженими проявляється автоматично. Тому в начальників відділень СПС, які працюють в УВП більше 5 років, при підвищенні особистісної тривожності, збільшується цинізм та негативне ставлення до роботи та ії̈ об’єктів.

Виявлений кореляційний зв'язок особистісної тривожності з редукцією особистих досягнень у респондентів всіх досліджуваних груп, який означає, що чим вищий рівень тривожності, тим більше працівники негативно оцінюють власні професійні досягнення та самих себе, відчувають некомпетентність в своїй професійній сфері i, навпаки.

Знайдено кореляційні зв'язки редукції досягнень 3 ситуативною тривожністю в I-й $(\mathrm{r}=0,589$ при $\mathrm{p} \leq 0,004)$ та II-й групі $(\mathrm{r}=0,467$ при $\mathrm{p} \leq 0,005)$, які свідчать, що при підвищенні стану тривоги в певних ситуаціях службової діяльності в молодих фахівців збільшується негативна оцінка результатів своєї роботи, вони відчувають свою некомпетентність, що може бути пов'язано з малим досвідом роботи та періодом адаптації.

Отже, ми виявили, що ситуативна та особистісна тривожність пов'язані з професійним вигоранням начальників відділень СПС 
УВП, а саме, чим вищий рівень тривожності, тим більший рівень професійного вигорання, за виключенням компоненту деперсоналізації в І-й групі працівників, що відповідно до кореляційного аналізу свідчить про наступне: чим вищий рівень деперсоналізації, тим менший рівень особистісної тривожності, і навпаки.

Для того, щоб встановити взаємозв'язки між професійним вигоранням та страхом, а також професійним вигоранням та напругою працівників СПС УВП проведено кореляційний аналіз між рівнем професійного вигорання (опитувальник «MBI» К. Маслач - С. Джексон) та індивідуально-психологічними особливостями особистості («16-ти факторний особистісний опитувальник Р. Кеттелла (16PF-105 - C)»)

Виявлені кореляційні зв'язки між напругою і редукцією особистих досягнень у респондентів, які працюють в установах від 1 до 3 років $(\mathrm{r}=0,966$ при $\mathrm{p} \leq 0,001)$, а також в начальників відділень СПС, які працюють в УВП від 3 до 5 років $(\mathrm{r}=0,437$ при $\mathrm{p} \leq 0,042)$, тобто при підвищенні напруги працівники СПС не можуть належним чином оцінювати свої професійні досягнення, можуть вважати себе непотрібними та безпомічними. Виявлена кореляція є двосторонньою, тому варто сказати, що за умови підвищення рівня редукції особистих досягнень, підвищуватиметься i стан напруги.

Також виявлено взаємозв'язки між три- вожністю та професійною деформацією працівників СПС УВП. Так, у респондентів, які працюють в установах менше 3 років кореляція не виявлена. У начальників відділень СПС, які працюють в установах від 3 до 5 років знайдений прямий кореляційний зв'язок між ситуативною тривожністю та професійною деформацією $(\mathrm{r}=0,537$ при $\mathrm{p} \leq 0,010)$, який свідчить про те, що підвищення стану тривоги впливає на розвиток професійної деформації, i навпаки, якщо рівень професійної деформації в респондентів буде підвищуватися, це впливатиме на збільшення ситуативної тривожності. У респондентів, які працюють в УВП більше 5 років встановлений прямий зв'язок між особистісною тривожністю та професійною деформацією ( $\mathrm{r}=0,360$ при $\mathrm{p} \leq 0,027)$, який означає, що при підвищенні особистісної тривожності, підвищується рівень професійної деформації і, навпаки.

Висновки. Таким чином, виявлені кореляційні зв'язки свідчать про те, що деструктивні психічні стани пов'язані з професійним вигоранням та професійною деформацією працівників соціально-психологічної служби установ виконання покарань. Вони негативно впливають на особистість начальників відділень СПС та їхню професійну діяльність, а також на розвиток професійного вигорання $\mathrm{i}$ професійної деформації. Особливо гостро ця проблема стосується молодих фахівців, які ще не адаптувалися до умов та специфіки професійної діяльності установ виконання покарань, 
не досить добре вміють регулювати свій психічний стан та контролювати свою поведінку. Тому деструктивні психічні стани в осіб, які працюють в УВП до 3 років виявляються на підвищеному рівні, що може призвести до появи компонентів професійного вигорання.

Перспективи подальших досліджень полягають у підборі ефективних засобів психологічної профілактики деструктивних психічних станів, компонентів професійного вигорання та професійної деформації.

\section{Список використаних джерел:}

1. Замула С. Ю. Профілактика професійної деформації персоналу установ виконання покарань: Посібник. / С.Ю. Замула, І.В. Пахомов, І.М. Рудніцька, В.О. Синєбок, В.В. Скороход, С.П. Шелест. - Біла Церква. 2011. -206 c.

2. Медведєв В. С. Професійна деформація співробітників пенітенціарних установ: Навч. посібник / В.С. Медведєв / МВС України. - Київ. Ін-т ВС. - К., 1996. - 80 с.

3. Профілактика професійного вигорання працівників соціальної сфери: метод. рекомендації / за заг. ред. М.Л. Авраменка, Всеукраїнський центр професійної реабілітації інвалідів. - Л., 2008. - 53 с

4. Чичуга М. М. Профілактика деструктивних психічних станів працівників соціально-психологічної служби установ виконання покарань України : автореф. дис. . канд. психол. наук : 19.00.06 / М. М. Чичуга. - Харків, 2016. -21 c.

5. Ятчук М. С. Особливості прояву окремих психічних станів працівників Державної кримінально-виконавчої служби у професійній діяльності / М.С. Ятчук // Fundamental and applied researches in practice of leading scientific schools. - № 22. - 2017. - C. 11-15.

6. Bianchi R., Schonfeld I., \& Laurent E. (2014) Is burnout a depressive disorder? A re-examination with special focus on atypical depression // International Journal of Stress Management, 21(4), P. 307-324.

7. Bianchi R., Boffy, C., Hingray, C., Truchot, D., \& Laurent, E. (2013) Comparative symptomatology of burnout and depression // Journal of Health Psychology, 18(6), P. 782-787.

8. Freudenberger H. J. (1974). "Staff burnout". Journal of Social Issues, 1974, 30 (1): P. 159-165.

9. Maslach C. (2003) Burnout: The Cost of Caring / C. Maslach, ISHK, 276 p.

10. Maslach C., Leiter, M. P., \& Jackson, S. E. (2012). Making a significant difference with burnout interventions: Researcher and practitioner collaboration. Journal of Organizational Behavior, 33, P. 296-300

11. Maslach C., Leiter, M.P. (2008) Early predictors of job burnout and engagement. Journal of Applied Psychology, 93 (3), P. 498-512.

\section{References (Transliteration):}

1. Zamula S. Iu. Profilaktyka profesiinoi deformatsii personalu ustanov vykonannia pokaran: Posibnyk. / S.Iu. Zamula, I.V. Pakhomov, I.M. Rudnitska, V.O. Syniebok, V.V. Skorokhod, S.P. Shelest. - Bila Tserkva. - 2011. $206 \mathrm{~s}$.

2. Medvediev V. S. Profesiina deformatsiia spivrobitnykiv penitentsiarnykh ustanov: Navch. posibnyk / V.S. Medvediev / MVS Ukrainy. - Kyiv. In-t VS. - K., 1996. $80 \mathrm{~s}$.

3. Profilaktyka profesiinoho vyhorannia pratsivnykiv sotsialnoi sfery: metod. rekomendatsii / za zah. red. M.L. Avramenka, Vseukrainskyi tsentr profesiinoi reabilitatsii invalidiv. - L., 2008. - $53 \mathrm{~s}$

4. Chychuha M. M. Profilaktyka destruktyvnykh psykhichnykh staniv pratsivnykiv sotsialno-psykholohichnoi sluzhby ustanov vykonannia pokaran Ukrainy : avtoref. dys. ... kand. psykhol. nauk : 19.00.06 / M. M. Chychuha. Kharkiv, 2016. - $21 \mathrm{~s}$.

5. Yatchuk M. S. Osoblyvosti proiavu okremykh 
psykhichnykh staniv pratsivnykiv Derzhavnoi kryminalnovykonavchoi sluzhby u profesiinii diialnosti / M.S. Yatchuk // Fundamental and applied researches in practice of leading scientific schools. - № 22. - 2017. - S. 11-15.

6. Bianchi R., Schonfeld I., \& Laurent E. (2014) Is burnout a depressive disorder? A re-examination with special focus on atypical depression. International Journal of Stress Management, 21(4), P. 307-324.

7. Bianchi R., Boffy, C., Hingray, C., Truchot, D., \& Laurent, E. (2013) Comparative symptomatology of burnout and depression. Journal of Health Psychology, 18(6), P. 782 -787 .

8. Freudenberger H. J. (1974). "Staff burnout". Journal of Social Issues, 1974, 30 (1): P. 159-165.

9. Maslach C. (2003) Burnout: The Cost of Caring . ISHK, $276 \mathrm{p}$.

10. Maslach C., Leiter, M. P., \& Jackson, S. E. (2012). Making a significant difference with burnout interventions: Researcher and practitioner collaboration. Journal of Organizational Behavior, 33, P. 296-300.

11. Maslach C., Leiter, M.P. (2008) Early predictors of job burnout and engagement. Journal of Applied Psychology, 93 (3), P. 498-512.

\section{Chychuha Maryna}

PhD in Psychology, Senior Professor of Practical Psychology of the Institute of Criminal-Executive Service, Kyiv (Ukraine)

\section{LIAISON OF DESTRUCTIVE MENTAL STATES OF THE SOCIAL-PSYCHOLOGICAL SERVICE WORKERS IN THE PENITENTIARY INSTITUTIONS COMBINED WITH BOTH PROFESSIONAL BURNOUT AND PROFESSIONAL DEFORMATION}

\section{ABSTRACT}

The liaison of destructive mental states of the social-psychological service workers of penitentiary institutions combined with both profes- sional burnout and professional deformation has been analyzed here in.

It is noted that the results of the empirical research indicate the low level of situational anxiety, the middle and elevated level of personal anxiety, intenseness and phobia of the socialpsychological service workers in the penitentiary institutions.

The middle level of professional burnout among respondents, as well as the beginner level professional deformation for workers with less than 5 years experience in the penitentiary institutions, and the middle level for workers with more than 5 years experience has been researched.

The correlations links of situational and personal anxiety and intenseness combined with the social-psychological service workers professional burnout have been revealed.

Thus, respondents who work in institutions less than 1 year found reverse correlation between their personal anxiety and depersonalization - a component of professional burnout, which indicates that with increasing personal anxiety, the negative and cynical attitude of young professionals towards work and convicts is reduced, and vice versa. It is noted that such a correlation may indicate the indifference of employees to their work and its result.

Direct correlative links between the personal anxiety and depersonalization of persons who work in the penitentiary institutions for more than 5 years has been founded. It means that with increase of personal anxiety the level of cynicism 
in regard to convicts and negative attitude towards own work will also increase.

The correlative links of the personal anxiety and reduction of the personal achievement has been found in all investigated groups of respondents which means the higher anxiety level, all the more negatively the workers evaluate their own professional achievements as well as themselves, feel their incompetence in professional field, and vice versa.

Direct correlative links of the situational anxiety and achievements reduction of the workers with less than 3 years experience of work in penitentiary institutions has been researched. It means the higher anxiety level, all the more negatively the young workers evaluate their own professional achievements, feel their incompetence in professional field in specific situations of their professional activity.

Direct correlative links between the intenseness and reduction of personal achievements of those who work less than 3 years has been found, i.e. the workers cannot properly evaluate their professional achievements being under stress.

Direct correlative links between the situational anxiety and professional deformation of the penitentiary institutions workers with more than 3 years' experience has been established. It was specified that in accordance to the revealed links at the anxiety level increasing the level of professional deformation has been noticed too.
Key words: destructive mental states, professional burnout, depersonalization, personal achievements reduction, personality professional deformation, the social-psychological service workers in the penitentiary institutions.

\section{Чичуга Марина Михайловна}

Кандидат психологических наук, старший преподаватель кафедры практической психологии Института уголовно-исполнительной службы, м. Киев (Украина)

\section{ВЗАИМОСВЯЗЬ ДЕСТРУКТИВНЫХ ПСИХИЧЕСКИХ СОСТОЯНИЙ СОТРУДНИКОВ УЧРЕЖДЕНИЙ ИСПОЛНЕНИЯ НАКАЗАНИЙ С ПРОФЕССИОНАЛЬНЫМ ВЫГОРАНИЕМ И ПРОФЕССИОНАЛЬНОЙ ДЕФОРМАЦИЕЙ}

Аннотация. В статье осуществлен анализ взаимосвязи деструктивных психических состояний сотрудников социальнопсихологической службы учреждений исполнения наказаний с профессиональным выгоранием и профессиональной деформацией.

Отмечено, что результаты эмпирического исследования свидетельствуют о выявленных у сотрудников социальнопсихологической службы УИС низкий уровень ситуативной тревожности, средний и повышенный уровень личностной тревожности, напряжение и страх.

Исследовано средний уровень профессионального выгорания у респондентов, а также начальный уровень профессиональной деформации у лиц, работающих в учреждениях 
исполнения наказаний менее 5 лет и средний уровень у работников со стажем службы более 5 лет.

Выявлены корреляционные связи ситуативной и личностной тревожности, а также напряжения с профессиональным выгоранием работников социально-психологической службы учреждений исполнения наказаний. Так, у респондентов, которые работают в УИС менее 1 года выявлено обратные корреляционные связи между личностной тревожностью и деперсонализацией - компонентом профессионального выгорания. Эти связи свидетельствуют, что при повышении личностной тревожности у молодых специалистов уменьшается негативное и циничное отношение к работе и осужденным, и наоборот. Замечено, что такая корреляция может означать безразличие персонала к своей работе и ее результатам.

Установлены прямые корреляционные связи между личностной тревожностью и деперсонализацией у лиц, работающих в УИС более 5 лет, свидетельствуют о том, что при повышении личностной тревожности повышается уровень цинизма по отношению к осужденным и негативного отношения к своей работе.

Выявлена корреляционная связь личностной тревожности с редукцией личных достижений у респондентов всех исследуемых групп. Такая связь означает, что чем выше уровень тревожности, тем больше работники негативно оценивают собственные профессио- нальные достижения и самих себя, чувствуют некомпетентность в своей профессиональной сфере и, наоборот.

Исследована прямые корреляционные связи ситуативной тревожности с редукцией достижений у работников со стажем службы в учреждениях исполнения наказаний менее 3 лет, свидетельствуют, что при повышении состояния тревоги в определенных ситуациях служебной деятельности в молодых специалистов увеличивается отрицательная оценка результатов своей работы, они чувствуют свою некомпетентность.

Выявлено прямые корреляционные связи между напряжением и редукцией достижений лиц, работающих в учреждениях от 1 до 3 лет, то есть при повышении напряжения работники не могут должным образом оценивать свои профессиональные достижения.

Установлены прямые корреляционные связи между ситуативной тревожностью и профессиональной деформацией у респондентов, работающих в учреждениях исполнения наказаний более 3 лет. Отмечено, что в соответствии с корреляциями, которые были выявлены, при повышении состояния тревоги у персонала повышается уровень профессиональной деформации.

\section{Ключевые слова: деструктивные пси-} хические состояния, профессиональное выгорание, эмоциональное истощение, деперсонализация, редукция личных достижений, про- 
фессиональная деформация, работники учре-

ждений исполнения наказаний. 